\title{
ASORTYMENT KSIĘGARSKI PIOTRA DUFOURA W ŚWIETLE KATALOGU Z 1793 ROKU
}

Głównym ośrodkiem kultury polskiego Oświecenia była Warszawa. Skupiło się w niej życie polityczne, ideowe i intelektualne, tutaj toczyły się najważniejsze sprawy i rozstrzygały losy kraju. W Warszawie kumulowały się więc wszystkie problemy, trudności i osiągnięcia, które spotkać można było także na pozostałych terenach Rzeczypospolitej. Najostrzej występowały tu konflikty, ale też wypracowane zostały najwyższe wartości, które zapewniły naszej kulturze jedność i ciągłość w latach podziału i niewoli.

Warszawa wiodła prym w rozwoju drukarń i księgarń mimo ogromnych trudności, zwłaszcza na początku, z powodu braku nawyku czytelniczego ówczesnego społeczeństwa. Drukarze i księgarze chcąc zachęcić do lektury szeroko propagowali swoją działalność za pomocą prospektów wydawniczych, obszernie opisując zapowiadane wydawnictwa; ogłoszeń wydawniczo-księgarskich, zamieszczanych w ówczesnych czasopismach oraz katalogów księgarskich informujących zarówno o krajowej produkcji wydawniczej, jak i o książkach importowanych.

Ten ostatni sposób reklamy książek pojawił się wraz z rozwojem handlu księgarskiego. Przedmiotem niniejszego artykułu jest analiza bibliologiczna jednego z takich katalogów, opracowanego i wydanego przez Piotra Dufoura w 1793 r. pt. Katalog różnych ksiąg $i$ komedii, znajdujacych się u Piotra Dufoura, konsyliarza nadwornego, drukarza J. K. M. i Rzplitej, dyrektora Drukarni Korpusu Kadetów, w Warszawie w Rynku Miasta Starej Warszawy pod nrem 58. Wybór tego właśnie źródła został podyktowany zarówno imponującą objętością, jak i ciekawą zawartością wydawnictwa. Jest to bowiem największy spośród wszystkich wydanych przez Dufoura katalogów, informujący najpełniej o specyficznym asortymencie jego księgarni.

„Wiek XVIII w Polsce, jak i w całej Europie, rozniecił pochodnię światła nauk i sztuk, zaktywizował nieczynne dotąd i uciskane warstwy społeczne" ${ }^{1}$.W literatu-

${ }^{1}$ M. Klimowicz, Oświecenie [w:] Historia literatury polskiej, pod red. K. Wyki, Warszawa 1980, s. 464. 
rze polskiego Oświecenia dokonał się rozwój gatunków i form literackich, uwarunkowany dążeniami do szybkiego odrobienia zaległości, przebudowy życia społecznego i kulturalnego, a motorem owych procesów stała się świadomość zagrożenia bytu państwowego. Nadało to dramatycznego charakteru próbom reform oraz podkreślało szczególną rolę uczestniczącej w nich literatury. Okres ten przyniósł nobilitację nie uznawanych do tej pory gatunków beletrystycznych i publicystyki. Oprócz adaptacji schematów fabularnych, przejętych ze współczesnej powieści europejskiej, wielką zdobyczą zarówno poezji, jak i prozy stanisławowskiej było unowocześnienie frazeologii języka, poszerzenie jego zasobów i przysposobienie go do wyrażania indywidualnych treści ${ }^{2}$.

W czasach stanisławowskich bujnie rozkwitła rodzima produkcja literacka. Ilość reklamowanych tego typu dzieł w omawianym katalogu, decyduje o tym, że zajmie ona pierwsze miejsce. W katalogu tym znalazło się 336 tekstów literackich polskich i obcych, w tym: 164 utwory dramatyczne, 139 utworów prozaicznych i 32 utwory poetyckie - co ilustruje tabela nr 1 .

Pod względem struktury językowej, dominująca rola przypadła 176 przekładom z języka francuskiego, drugie miejsce zajęła literatura w języku polskim - 92 tytuły, a dalsze miejsca to przekłady w językach: włoskim - 24 tytuły, niemieckim 16 tytułów, angielskim - 5 tytułów, łacińskim - 3 tytuły oraz po 2 z języka greckiego i rosyjskiego (zob. tabela nr 2).

\section{LITERATURA DRAMATYCZNA}

Najwięcej uwagi poświęcił Dufour reklamie utworów dramatycznych. Wśród nich pierwsze miejsce - 93 teksty - zajęły przekłady z języka francuskiego, 35 - stanowiła literatura polska, 22 - przekłady z języka włoskiego, 10 - z języka niemieckiego i po 2 - z języków: rosyjskiego i angielskiego (zob. tabela nr 2).

Termin dramat od około 1770 roku oznaczał każdy utwór przeznaczony do inscenizacji teatralnej ${ }^{3}$.

W Katalogu Dufoura znalazły się: komedie, dramy, tragedie, opery zarówno oryginalne autorów polskich, jak i przez nich tłumaczone lub parafrazowane ze źródeł obcych. Dramę zdecydowanie zdominowały sztuki komediowe.

Komedia poważna, tzw. drama mieszczańska lub sentymentalna, opierała się na założeniach, które dla teatru francuskiego sformułował Denis Diderot w Synu naturalnym, ogłoszonym w 1757 roku. Roztrząsała ona tematy moralne w sprawach honoru, godności, majątku. Tematy te zaś, umieszczano na tle życia rodzinnego po to, by uczyły dobroci i poświęcenia, a odwodziły od zbrodni i występków ${ }^{4}$. Wśród najczęściej występujących tego typu komedii można wymienić utwory: Moliera Matżéstwo przymuszone. Komedia we 2 aktach, Wwa 1782, Doktor z musu. Ko-

2 Tamże, s. 465-467.

3 J. Pawłowiczowa, Drama [w]: Stownik literatury polskiego Oświecenia, pod red. T. Kostkiewiczowej, wyd. 2, Wrocław 1991, s. 70.

${ }^{4}$ Tamże, s. 71. 
media we 3 aktach, Wwa 1782, Frantostwa Panfila. Komedia we 3 aktach, Wwa 1780, Krętolewicz. Komedia w 5 aktach, Wwa 1778, Mąż zawstydzony. Komedia we 3 aktach, Wwa 1779, Prostakiewicz. Komedia we 3 aktach, Wwa 1784 i Szkoła mężów, Wwa 1782; L. S. Merciera - Odwaga dla szczęścia, Wwa 1785, Nędznik, Wwa 1774; Ph. N. Destouchesa - Dobosz mocny czyli mąż czarnoksiężnik, Wwa 1787, Sam nie wie czego mu się chce, Wwa 1783; P. C. Miravaux - Przesad przezwyciężony, Wwa 1782, Wyspa niewolników, Wwa 1782, Fatszywe zwierzenia się, Wwa 1784; M. J. Sédaina - Zakład nieprzewidziany, Wwa 1778, Umart i ożenit się, Wwa 1779; Beaumarchais'go - Cyrulik sewilski albo ostrożność niepożyteczna, Wwa 1780 i C. Goldoniego - Dziwak dobroczynny, Wwa 1785 oraz Mecenas poczciwy, Wwa 1779 .

Z mniej znanych autorów obcych Dufour reklamował m.in.: J. A. Romangesiego - Miłość odnowiona, Wwa 1781 czy J. Pauersbacha-Prawo braminów czyli Wdowę indyjska, Wwa 1783.

Termin drama mieszczańska pojawił się w Polsce na karcie tytułowej Zbiega z 1774 roku - spolszczonej sztuki L. S. Merciera Le Déserteur ${ }^{5}$. Propagatorem tego gatunku był Franciszek Zabłocki. Pisał on komedie satyryczno-obyczajowe „zabawne i uczące zarazem”, przepojone pierwiastkiem prawdziwego humoru, łączące ze sobą elementy komediowe z groteską, farsą i operą. Był także tłumaczem komedii autorów zachodnich, takich jak: Molier, Diderot i Destouches, a także mniej znanych, tj.: Romangesi czy Le Grand, które adaptował, nasycając ich treść polskimi realiami epoki. Z jego twórczości Dufour polecał m.in.: Amfitrio (wg Moliera), Wwa 1783, Ociec dobry (wg Diderota), Wwa 1780 oraz dwie komedie Destouchesa: Przeszkoda nieprzewidziana, Wwa 1776 i Filozof żonaty, Wwa 1781.

W omawianym Katalogu znalazła się też grupa komedii, zwanych przez historyków literatury - obyczajowymi warszawskimi, których twórcy - choć mniej znani - wskazywali na nowe dla epoki zjawisko - mianowicie kształtowanie się zawodu literata, dla którego pisanie czy tłumaczenie było pracą zawodową. Komedie te łączyły satyrę z zabawą na tle ówczesnej Warszawy, a w miejsce dydaktyki wprowadzano ironię i humor. Są to m.in.: Małżeństwo w rozwodzie D. B. Tomaszewskiego, Wwa 1781, Wet za wet G. Broniszewskiego, Wwa 1787 oraz O tak po warszawsku, Wwa 1780.

Dramaturgiem był również J. Baudoin, który tłumaczył z Moliera: Męża oszukanego, Wwa 1780 i Świętoszka zmyślonego, Wwa 1777, a z J. F. Régnarda: Dziedzica, Wwa 1777 i Roztargnionego, Wwa 1778.

Wśród polskich autorów dramatycznych najczęściej występującym było nazwisko autora, aktora i dyrektora Teatru Narodowego - Wojciecha Bogusławskiego. Tłumaczył on na język polski m.in. komedie: Moliera, Ślub modny, Wwa 1780 i Szkołę kobiet, Wwa 1781 oraz C. Goldoniego, pt. Czekina albo cnotliwa panienka, Wwa 1783. 
Adam Kazimierz Czartoryski tłumaczył na język polski komedie drugorzędnych autorów: Garricka i Regnarda, a są to w omawianym Katalogu: Kawa, Wwa 1779, Panna na wydaniu, Wwa 1774, Bliźnięta, Wwa 1775 oraz Gracz, Wwa 1774.

Z utworów znanego publicysty, jezuity i współredaktora „Monitora” - Franciszka Bohomolca - znalazły się w Katalogu m.in.: Podejrzliwi, Wwa 1781 i Nędza uszczęśliwiona, Wwa 1778.

Klasyczne dramaty to przede wszystkim: Voltaira - Alzyra, Wwa 1779, Meropa, Wwa 1779 i Zaira, Wwa 1787.

\section{PROZA}

Proza była reprezentowana głównie przez: 83 przekłady z języka francuskiego, 40 - tekstów literatury oryginalnej w języku polskim, 6 - to przekłady z języka niemieckiego, po 3 - z języka łacińskiego i angielskiego oraz po 2 - z języka greckiego i włoskiego (zob. tabela nr 2).

Analiza Katalogu pozwoliła stwierdzić, iż przeważającą część prozy stanowiła powieść, głównie francuska.

Powieść w czasach stanisławowskich była gatunkiem nowym, najczęściej zwanym romansem. Oświeceni, choć przeciwni tradycyjnemu romansowi, posługiwali się jednak tym terminem, dodając do słowa „romans” pojęcia wartościujące. I tak, aprobowaną powieść nowożytną zwali „dobrym” romansem ${ }^{6}$. Rozwój nowoczesnej powieści był charakterystycznym zjawiskiem w kulturze literackiej czasów stanisławowskich. Zainteresowanie nią wyraziło się przede wszystkim w licznych thumaczeniach z języków obcych.

Szczególną popularnością w Polsce cieszyła się powieść zachodnioeuropejska. Popularność ta wynikała z konstrukcji nowego oświeceniowego bohatera. Był to człowiek przeciętny, stawiany w coraz to nowych sytuacjach i okolicznościach wzbogacających jego wiedzę i kształtujących poglądy. Dlatego często buntował się przeciwko niesprawiedliwym normom obyczajowym feudalizmu? .

Dufour oferował czytelnikom w 1793 roku m.in. polskie przekłady następujących utworów obcych: Przypadki Telemaka Fénelona, Wwa-Lipsk 1775, Listy perskie Montesquieu, Drezno 1778, Podróże kapitana Guliwera Swifta, Supraśl 1784, Historia i awantury Roderyka Random Smolletta, Wwa 1785, Historia czyli Dzieje i przygody przedziwnego Don Quiszotta z Manszy Cervantesa, Wwa 1786, Przypadki Robinsona Kruzoe Defoe'go, Wwa 1775, Królowa dziwak Rousseau, Lublin 1781, Diabet rozkochany Cazotta, Wwa 1786, Nancy albo nieszczęścia z nieroztropności i zawiści pochodzace Arnauda, Wwa 1778 oraz Argensa Niestałość w mitości czyli awantury markiza de Vandreville, w przekładzie F. Makulskiego, Wwa 1793.

W 1776 roku ukazała się pierwsza polska powieść edukacyjna pt. Mikołaja Doświadczyńskiego przypadki I. Krasickiego, Wwa 1776, która stała się źródłem

${ }^{6}$ Z. Sinko, Powieść [w]: Stownik literatury ..., s. 452.

7 D. Hombek, Reklama wydawnicza i ksieggarska w , Gazecie Warszawskiej” w latach 17641795, Kielce 1988, s. 129. 
inspiracji kolejnej powieści polecanej przez Dufoura, pt. Wojciech Zdarzyński, życie i przypadki swoje opisujacy D. Krajewskiego, Wwa 1785. Podobny charakter miał spolszczony z francuskiego Polak w Paryżu J. Rutlidge'a, Wwa 1787. Powieść edukacyjna przedstawiała etapy zdobywania życiowej mądrości oraz kształtowanie się poglądów społeczno-kulturalnych i obyczajowych bohatera-szlachcica, od dzieciństwa i młodości poprzez pobyt w fikcyjnej krainie, aż do powrotu do własnego środowiska i próby zreformowania go ${ }^{8}$.

Powieść traktat zaś, był to dyskurs głównego bohatera na temat problemów życia społecznego i politycznego $\mathrm{w}$ formie traktatu, uzupełniony elementami opowiadania i publicznej retoryczno-persfazyjnej wypowiedzi ${ }^{9}$.

Spośród tego typu powieści Dufour zamieścił jedynie informację o Obywatelu J. K. Kossakowskiego, Wwa 1788.

Rozważania o aktualnych problemach ówczesnego świata, ukrytych pod kostiumem wydarzeń historycznych przedstawiały następujące powieści pseudohistoryczne ${ }^{10}$ : Historia na dwie księgi podzielona I. Krasickiego, Wwa 1779, Rzepicha, matka królów F. S. Jezierskiego, Wwa 1790 i Leszek Biały D. Krajewskiego, Wwa 1792.

Mniejszymi formami fabularnymi od powieści były powiastki, wzorowane na francuskich contes. Miały one pouczać, a często poprzez motywy orientalne, przygodowe, mitologiczne i klasyczne - wprowadzać element rozrywki ${ }^{11}$. Z osobno wydanych zbiorów powiastek Dufour polecał m.in.: Powieści moralne J. F. Marmontela, w przekładzie T. K. Węgierskiego, t. 1-3, Wwa 1776-1777, Czytania zabawne czyli Wybór przygód, powieści moralnych i anekdotów z różnych autorów wybrane, Wwa 1788 oraz Powiastki literatury polskiej czyli Powieści moralne w języku polskim, thumaczenia J. M. Skoraszewskigo, Wwa $1792^{12}$.

Najwybitniejszą realizacją tego gatunku były Powieści wschodnie I. Krasickiego, których część opublikowana została w Listach i pismach różnych, t. 1-2, Wwa $1786-1788$.

Twórcą powiastek pisanych po francusku i wtopionych w: Podróż do Turek i Egiptu, Wwa 1789 i Podróż do Maroka, Wwa 1792 był J. Potocki.

Z autorek powieści i powiastek Dufour oferował: M. A. de Gomez Dni zabawne, t. 1-8, Wwa 1791, S. de Genlis Adele i Teodor czyli Listy o edukacji, w thumaczeniu K. Czermińskiej, t. 1-3, Kr. 1787-1788 i Teatr dla społeczności, w przekładzie ks. Ładowskiego, Wwa 1793, M. le Prince de Beaumont Dokończenie Magazynu panieńskiego czyli nauki dla dam, tłumaczenia E. Dębickiego, Wwa 1774 oraz Listy Jejmość pani du Montier, przełożone przez K. Kuropatnicką, Wwa 1780 a także

\footnotetext{
${ }^{8}$ Z. Sinko, Powieść [w:] Stownik literatury ..., s. 456-457.

9 Tamże.

10 Tamże, s. 458.

${ }^{11}$ I. Kitowiczow a, Powiastka [w:] Stownik literatury ..., s. 444.

${ }^{12}$ Dufour wydawał powiastki na mocy nadanego mu przywileju królewskiego z 6 II 1783 r. Zob.:
} M. Ju da oprac. i wyd., Privilegia typographica Polonorum. Polskie przywileje drukarskie 1493-1793, Lublin 2010, s. 423-424. 
M. J. Riccoboni Kobieta jakich mało, Wwa 1785 czy tłumaczone przez A. Łopuskiego Listy milady Julii Katesby do milady Heleny Kambley przyjaciótki swojej, Wwa 1778.

Sporą grupę wśród powieści zajęły utwory anonimowe, takie np. jak: Cnota $w$ drodze do szczęścia czyli Aspazja. Przypadki angielskie, Wwa 1787, Dwie suttanki. Powieść turecka, Wwa 1788, Filozofka czyli Rozmowa damy z filozofami, Kr. 1784, Niestatek szczęścia ludzkiego czyli Przypadki p. Samuela de Louvry, Wwa 1790, Rensi, Wwa 1787, Zimeo, Wwa 1779 oraz Złote jarzmo matzeńskie, Kr. 1784.

Czasy Oświecenia przyniosły także szereg interesujących pamiętników i biografii m.in.: Pamiętniki filozofa samotnika czyli czlowieka z innego świata, Wwa 1784, J. K. Bogusławskiego Życia sławnych Polaków krótko zebrane, Wwa 1788, A. L. Thomasa Życie i pochwata Maksymilina z Bethune, w przekładzie S. Tarnowskiego, Kr. 1787, Życie Piotra III, cara moskiewskiego, męża Katarzyny II, Kr. 1789 oraz Jonsaca Życie Stanisława Jabłonowskiego, kasztelana krakowskiego, t. 1-3, Wwa 1789-1790.

Przełom, jaki dokonał się w dobie Oświecenia, spowodował ożywienie polityczne, w dążeniu do naprawy państwa i przeprowadzenia reform społecznych, które miałyby zabezpieczyć kraj przed zagrożeniami z zewnątrz. Zgodnie z potrzebą chwili Dufour reklamował następującą literaturę polityczną: Przestrogi dla Polski S. Staszica, t. 1-2, 1790 i O poddanych polskich J. Pawlikowskiego, Kr. 1788.

Odrębną grupę wśród omawianych publikacji politycznych stanowiły diariusze, czyli, dzienniki z zapiskami dotyczącymi bieżących wydarzeń. I tak, Dufour sprzedawał m.in.: Diariusz podróży Jana III z Krakowa pod Wiedeń, Kr. 1784, Diariusz sejmu wolnego ordynaryjnego sześcioniedzielnego roku pańskiego 1780, Wwa, Diariusz podróży Najjaśniejszego Stanisława Augusta na Ukrainę i bytność w Krakowie aż do powrotu do Warszawy dnia 22 lipca roku 1787 A. Naruszewicza, Wwa 1787 oraz Diariusz sejmu ordynaryjnego pod Zwiazkiem Konfederacji Generalnej Obojga Narodów w Warszawie rozpoczętego roku pańskiego 1788, aż CXXXVII dnia 10 sierpnia 1790, t. 1-3, Wwa 1790.

W Katalogu znalazły się też dwie bardzo głośne polemiki literackie, dotyczące wydanej w 1784 roku powieści Podolanka wychowana w stanie natury, życie i przypadki swoje opisujaca ${ }^{13}$. Pierwsza pt. Dialog czyli Rozmowa Podolanki z jej mężem, Wwa 1784 oraz druga List Sandomierzanki do Podolanki, Kr. 1784.

Zbiory anegdot i bajek reprezentowane były przez: Zabawki bardzo ciekawe i wesołe dla każdego wieku i stanu stużace czyli Zbiór anekdotów ..., Kr. 1784; Fabuły Ezopa, Wwa 1787; Bajki F. D. Kniaźnina, Wwa 1785 oraz Anekdoty oryginalne o Piotrze Wielkim zebrane ... J. P. Staehlina, Kr. 1789.

Spośród pism autorów starożytnych Dufour polecał: filozofa i humanisty holenderskiego - Erazma z Rotterdamu, Bunt w Antiochii, Kr. 1792, poety greckiego Hezjoda, Dzieła dochowane wszystkie, Kr. 1790 i Lipsiusa Myśli i zdania z pism

${ }^{13}$ A. K. Guzek, Polemiki literackie [w:] Stownik literatury ..., s. 440-441. 
... wyjęte, Kr. 1789, a także Podróż Fortuny do Grecji, opisana przez Tychogenesa sławnego pomyślnościa życia w Sparcie, Kr. 1788.

\section{POEZJA}

W twórczości poetyckiej dominowała literatura oryginalna w języku polskim 18 utworów; następne miejsca zajęło: 9 przekładów z języka francuskiego, 3 $\mathrm{z}$ języka niemieckiego oraz $2-\mathrm{z}$ łaciny (zob. tabela $\mathrm{nr} 2$ ).

Najczęściej, bo 8 razy wśród autorów utworów poetyckich, pojawiło się nazwisko W. I. Marewicza, twórcy m.in.: Dorywczych zabawek, Wwa 1790, Sielanek, Wwa 1788 oraz Różnych wierszy, Wwa 1788.

Następne miejsce zajął I. Krasicki i jego: Wiersze, Wwa 1784 i poematy: bohaterski pt. Wojna chocimska, Wwa 1780 oraz heroikomiczny - Myszeidos, Wwa 1775.

Obok utworów autorów polskich znalazły się też przekłady, m.in.: Pukiel Belindzie ustrzyżony i porwany A. Pope, Wwa 1788, Epigrammata wybrane J. Owena, Wwa 1790 i Voltaira Rymopismo, brak identyfikacji bibliograficznej.

\section{LITERATURA NAUKOWA}

Wśród książek naukowych przeważały pod względem językowym dzieła w języku polskim - 21, następne miejsce zajęło 16 przekładów z języka francuskiego, a dalsze: 6 - z języka niemieckiego oraz po jednym z języka włoskiego i angielskiego (zob. tabela nr 2).

Piśmiennictwo naukowe to przede wszystkim kosztowne, wielotomowe wydawnictwa encyklopedyczne, takie jak: z zakresu nauk humanistyczno-społecznych (które zdecydowanie dominowały - było ich 26): Nowy dykcjonarz historyczny M. de Chaudona, w przekładzie W. R. Karczewskiego, Wwa $1783-1788^{14}$ czy Dykcjonarz przystów $w$ czterech językach, t. 1-2, Wwa 1792. Z zakresu nauk matematyczno-przyrodniczych i technicznych, np. Dykcjonarz powszechny medyki, chirurgii i sztuki hodowania bydlat czyli Lekarz wiejski N. Demargue'a, Wwa 1787, L. Echarda Dykcjonarzyk geograficzny, Wwa $1782^{15}$ oraz Dykcjonarz stużacy do poznania historii naturalnej i różnych osobliwszych starożytności, które ciekawi w gabinetach znajduja, thumaczenia ks. Sadowskiego, Kr. 1783.

W omawianym Katalogu znalazły się dwie prace F. Naxa, które dały początek polskiemu piśmiennictwu ekonomicznemu, tj. Uwagi nad uwagami czyli Obserwacje nad ksiażka, która w roku 1785 wyszła pod tytutem: Uwagi nad życiem Jana Zamoyskiego, Wwa 1789 i Wykład poczatkowych prawidet ekonomiki politycznej, Wwa 1790.

„W nauce zarówno o prawie, jak i o państwie przeważyło stanowisko fizjokratów francuskich. Uczeni polscy nie ograniczali się jednak do recepcji ich poglądów,

\footnotetext{
${ }^{14}$ M. Juda, Privilegia typographica ..., s. 423- 424.

15 Tamże.
} 
lecz rozwinęli je, głównie w zakresie prawa natury oraz «naturalnego» prawa politycznego i narodów" ${ }^{16}$. Z zakresu obu tych dyscyplin Dufour reklamował m.in. G. Filangieriego Naukę prawodactwa, przełożoną przez W. R. Karczewskiego, Wwa 1791, J. K. Bogusławskiego O doskonatym prawodactwie, Wwa 1786, A. Trębickiego Prawo polityczne i cywilne Korony Polskiej i Wielkiego Księstwa Litewskiego, Wwa 1789-1791, M. J. Mniszcha Układ prawodawstwa, Wwa 1777, J. G. Heineciusa Ustanowienia prawa cywilnego w sposobie łatwym zebrane, w przekładzie K. Meciszewskiego, t. 1-2, Kr. 1785-1786 oraz Zbiór rezolucji Rady Nieustającej, cz. 1-4, Wwa $1780-1788^{17}$.

„Literatura naukowa tłoczona w polskich oficynach w latach 1750-1820 nosi w sobie wszystkie wady i zalety właściwe nauce polskiego Oświecenia. Ambitny program epoki, by wychować i wykształcić nowego człowieka miał być realizowany dzięki zreformowanemu szkolnictwu - stąd wynikał ogromny udział literatury podręcznikowej w oświeceniowej produkcji wydawniczej” ${ }^{18}$. Stanowiły ją: podręczniki i opracowania pouczające i kształcące uczniów oraz poradniki metodyczno-wychowawcze dla nauczycieli i rodziców. Dufour polecał np. wykład z francuskiego pt. O fizycznej i moralnej ptci żeńskiej, Wwa 1789, Przepisy od Komisji Edukacji Narodowej pensjomistrzom i mistrzyniom dane, Wwa b.r., Sposób zaszczepienia w dzieciach obyczajów i nauk, podany rodzicom i tym, którzy się zatrudniaja pierwiastkowym ich przysposobieniem do tych dwóch zamiarów, Kr. 1784, M. Prokopowicza Sposób nowy, najłatwiejszy pisania i czytania razem dla panienek, z przypisami dla nauczycielek, Kr. 1790, S. Czochronia Uwagi moralne gruntujace się na prawie natury i religii dla wiadomości i pożytku młodzieży narodowej, Kr. 1782, A. K. Czartoryskiego Definicje różne przez pytania i odpowiedzi dla Korpusu Kadetów, Wwa 1790 oraz Szkołę szczęśliwości J. R. Sigauda, w thumaczeniu K. Kwiatkowskiego, t. 1-2, Wwa 1789 .

Filologię reprezentowały dwie pozycje: pierwsza J. Maguarta Gramatyka niemiecka stosowana do pojętności umiejących swój język a uczacych się po niemiecku Polaków, Wwa 1786, druga zaś to Gramatyka francuska dla dam i kawalerów uczacych się francuskiego zebrana i sposobem najnowszym ułożona, Kr. 1784.

Wśród książek naukowych Dufour anonsował także: V. Mignota Historię turecka, w przekładzie D. Szybińskiego, t. 1-5, Wwa 1779-1781 oraz J. K. Trzcińskiego Dysertację o wzroście nauk wyzwolonych i mechanicznych, Kr. 1787.

Najliczniejszą grupę spośród książek matematyczno-przyrodniczych stanowiło piśmiennictwo propagujące wzory nowoczesnego rolnictwa z krajów zachodnioeuropejskich, takie np., jak: J. Priestleya Nauka o napuszczaniu wody powietrzem kwaskowym, w trzech częściach zamknięta, w tłumaczeniu A. J. Trzcińskiego, Kr. 1787, J. G. Eisena Nauka o powszechnym roślin suszeniu, Wwa 1789, a także

${ }^{16}$ D. Hombek, Reklama wydawnicza ..., s. 108.

${ }^{17}$ M. Juda, Privilegia typographica ..., s. 423-424.

18 A. Żbikowska-Migoń, Książka naukowa w kulturze polskiego Oświecenia, Wrocław 1977, s. 55 . 
S. B. Jundziłła Opisanie roślin w prowincji W. Ksiesstwa Litewskiego naturalnie rosnacych, wedtug układu Linneusza, Wil. 1791 i J. P. Biretowskiego Wiadomość ciekawa czyli O skutkach i mocy zbóż wszelkich, jarzyn i ziół różnych tak ogrodowych, jako i polnych, Wil. 1777.

Rangę oddzielnej dyscypliny naukowej w ramach nauk rolniczych zyskała w Oświeceniu weterynaria. Do jej rozwoju w głównej mierze przyczyniło się nasilenie chorób bydła ${ }^{19}$. Jednym z wartościowych opracowań tego typu była tłumaczona z francuskiego przez A. Pietraszkiewicza Apteczka końska z przyłaczeniem uwag nad ospica owiec, Wwa 1785 oraz P. Buchoza Suplement do Apteczki końskiej, Wwa 1785.

Dufour oferował w Katalogu trzy podręczniki medyczne: T. Weichardta Anatomię to jest Nauke poznania czesści ciała ludzkiego, Kr. 1786 i dwa przekłady z francuskiego: Uwiadomienie krótkie, lecz bardzo interesujące, o skutkach nieszczęśliwych, na zdrowie każdego spływajacych, z dobrowolnej polucji czyli samogwałtu, Kr. 1787, J. Floresa Lekarstwo proste, łatwe i mało kosztujace, nowo odkryte $w$ królestwie Gwatymala ... do zupetnego i pewnego wyleczenia szankru, trąu $i$ w ogólności tego wszystkiego, co należy do chorób wenerycznych stużace, a do pojęcia wszystkich objaśnione, tłumaczenia F. Grasseta, Wwa 1784.

„W osiemnastowiecznej geografii dominowały dwa nurty: geografii fizycznej obejmującej zagadnienia z zakresu matematyki, astronomii, fizyki i przyrodoznawstwa oraz geografii gospodarczej, która zyskała w Polsce duże znaczenie. W ówczesnym piśmiennictwie geograficznym przeważał kierunek opisowy, zaś większość dzieł to podręczniki opracowane pod wpływem Komisji Edukacji Narodowej"20. Spośród nich pojawiły się w omawianym Katalogu następujące dwa przekłady R. Ładowskiego tj.: Opisanie wysp Pelew w czesści zachodniej Oceanu Spokojnego leżacych H. Wilsona, t. 1-2, Wwa 1792 oraz Podróż do różnych krajów Europy i Azji Ph. Avrila, Wwa 1791.

Z zakresu chemii reklamował - J. A. Trzcińskiego Opisanie przyczyn fizycznych trzessienia ziemi, Kr. 1787, a bardzo bliskiej jej - historii naturalnej, tłumaczoną z niemieckiego przez J. I. Przybylskiego Historię naturalna ekonomiczna rolnicza, t. 1-4, Kr. 1786-1787 oraz R. Ładowskiego Historię naturalna Królestwa Polskiego, Kr. 1780.

Wojskowość zaś, reprezentowała książka J. Cieciszowskiego pt. Początki miernictwa dla młodzieży aplikującej się do stanu wojskowego, Kr. 1786.

\section{PUBLICYSTYKA}

„Epoka oświecenia nie miała jeszcze sprecyzowanego, ani zastępczego terminu «publicystyka». Pojęciem tym określano niebeletrystyczne wypowiedzi piśmiennicze prozą, traktujące o aktualnych zjawiskach społecznych i naświetlające je

19 D. Hombek, Reklama wydawnicza ..., s. 99.

20 Tamże, s. 97. 
z punktu widzenia określonej orientacji społeczno-politycznej w celu pozyskania dla niej opinii publicznej" ${ }^{21}$.

Piśmiennictwo tego typu przybierało formy od wielkich traktatów o sprawach ustrojowych poprzez drobne publikacje w czasopismach do niewielkich wypowiedzi w broszurach lub ulotkach ${ }^{22}$.

Częstą praktyką, którą wówczas stosowano, było pomijanie nazwiska autora, drukarza i miejsca druku bądź podawanie fałszywych danych bibliograficznych. Zabiegi te miały uchronić autora przed poważnymi konsekwencjami politycznymi. Dużą część pism rozpowszechniano w rękopisach, np. w okresie barskim tylko jedną dziesiątą stanowiło piśmiennictwo publicystyczne - drukowane. Działo się tak dlatego, że drukarnie były w tym czasie wyłącznie w rękach zakonnych, a te chcąc ustrzec się przed represjami politycznymi nie godziły się na publikację wielu tekstów. Sytuacja ta zmieniła się po pierwszym rozbiorze, kiedy to coraz więcej publicystyki wydawano drukiem, a nawet ją anonsowano nie tylko na łamach prasy, ale i regularnie w katalogach księgarskich ${ }^{23}$.

Publicystyka czasów Oświecenia była wielojęzyczna. W omawianym Katalogu zdecydowanie dominowały pisma w języku polskim - było ich 20; drugie miejsce zajęły 3 teksty francuskie, a pozostałe 2 - niemieckie (zob. tabela $\mathrm{nr} 2$ ).

Publicystyka podejmowała tematykę związaną z najważniejszymi sprawami ustrojowymi, tj. udziału społeczeństwa w kierowaniu państwem, administracją, sądownictwem, wojskiem, np.: J. Krzywkowskiego Gospodarstwo polityczne, Wwa 1791, w szczególności liberum veto Forme constitutionelle décrétée paraclamation dans la séance suivante du 5 May 1791, Wwa 1791 i sukcesji tronu F. S. Jezierskiego O bezkrólewiach w Polszcze $i$ wybieraniu królów począwszy od śmierci Zygmunta Augusta Jagietly aż do naszych czasów, brak identyfikacji bibliograficznej.

Poruszano: sprawy wyznaniowe statusu duchowieństwa i stosunku do różnowierstwa, miejsca zakonów w społeczeństwie; problemy ekonomiczne dotyczące handlu krajowego i zagranicznego, systemu monetarnego, podatków (np. O podatkowaniu), banków, ceł, udziału przybyszów w handlu krajowym; sprawy narodowościowe; sprawy społeczne w kwestii chłopskiej i mieszczańskiej. Dużo uwagi poświęcano też sprawom wychowania, w tym m.in. systemowi szkolnictwa, metodom wychowawczym w pracy (T. Morskiego Myśli o potrzebie i sposobach przysposobienia młodzieży do stużby dyplomatycznej w Polszcze, Wwa 1792) oraz sprawom obyczajowym, tradycji, stosunkowi do cudzoziemszczyzny, zagadnieniom nauki, sztuki, literatury i moralistyki (np. J. Sołtykowicza Wywód o skutecznym sposobie zaprowadzenia i ugruntowania dobrych obyczajów, Kr. brak roku) ${ }^{24}$.

Teksty publicystyczne przybierały różne formy, np. dyskusje i polemiki - poruszające ważne kwestie polityczne - już w samych tytułach odwoływały się do pisma

\footnotetext{
${ }^{21}$ Z. Goliński, Publicystyka [w:] Stownik literatury ..., s. 489.

22 Tamże, s. 490.

${ }^{23}$ Tamże.

${ }^{24}$ Tamże, s. 491-492.
} 
podstawowego: Uwagi nad pismem z druku wyszłym pod tytułem: Usprawiedliwienie się J. W. Dluskiego ... z manifestu przeciwko ustawie 3 Maja 1791 roku, b.m. i r. czy Uwagi polityczne do prawidet religii i zdrowej filozofii zastosowane, tyczace się władzy kościelnej, ulepszenia katolickiego obrządku greckiego, nie utwarzania hierarchii nieunickiego kościoła w krajach Rzeczypospolitej $i$ udzielania sprawiedliwości poddaństwu polskiemu, Wwa 1789.

Największą popularność zyskały jednak rozprawki dyskursywne. Zawierały one określone tezy i argumenty na ich poparcie, czasem zbijały zdania przeciwne, przybierając postać kazań lub przemówień agitacyjnych ${ }^{25}$, czego przykładem była: Próbka pióra bezstronnego obywatela nad stanem teraźniejszym i przyszłym Rzeczypospolitej Polskiej, K. Kwiatkowskiego, Wwa 1791.

Mocno zbliżone do rozprawki dyskursywnej były różnego rodzaju głosy, mowy, wota, przymówienia się, zdania wygłaszane na sejmach. Zachowywały one wszelkie cechy jawności, tj. nazwisko autora, okoliczność wypowiedzi, datowanie najczęściej dzienne ${ }^{26}$. Wśród nich Dufour polecał w Katalogu: Mowy za czterema stanami: kupieckim, rolniczym, żotnierskim i ludzi uczonych, thumaczone przez F. Barssa, Wwa 1775 czy J. I. Przybylskiego Mowa przy pierwszym rozdawaniu nagród dla cnót czynnych i użytecznych społeczności. Ku uwiecznieniu słodkiej pamiątki bytności w województwie krakowskim Stanisława Augusta. Podtug projektu JWJP Feliksa Oraczewskiego ... na Zwiazek Filantropów czyli Przyjaciót Ludzkości dnia 30 grudnia roku 1787 miana, Kr. 1788.

Nie mniej popularną formą wypowiedzi były listy, które w bezpośredniej rozmowie korespondentów poruszały bieżące zagadnienia polityczne i społeczne ${ }^{27}$. W omawianym Katalogu znalazły się trzy takie publikacje: Listy przyjacielskie J. F. Carosiego, Wwa 1781, Listy possesora dóbr pojezuickich do przyjaciela na Ukrainie, Wwa 1776 i Zdanie moje o pojedynkach czyli List oficera francuskiego do jednego swojego przyjaciela, Wwa 1776.

\section{LITERATURA RELIGIJNA}

Literatura religijna reprezentowana była przez 14 tytułów, z czego 10 stanowiły teksty w języku polskim (zob. tabela nr 2).

Książki do nabożeństwa to m.in.: Ćwiczenia duchowne albo Rekolekcje ośmiodniowe do odnowienia ducha zakonnym osobom stużace, Kr. 1786, Nabożeństwo podczas burzy i nawatności, b.m. 1782, Nabożeństwo chrześcijańsko-katolickie $w$ codziennych modlitwach dla wszelkiego stanu ludzi, osobliwie w matzeńskim stanie żyjacych, Kr. 1783.

Niemałym uznaniem cieszyły się też kazania i listy, reprezentowane w Katalogu przez takie np. druki: J. Męcińskiego Kazania w niedziele całego roku ..., t. 102, Kr. 1786-1787, Kazania na święta catego roku 1781 w Katedrze Krakowskiej miane,

\footnotetext{
25 Tamże, s. 493-494.

26 Tamże.

27 Tamże, s. 494-495.
} 
t. $1-2$, Kr. $1782-1783$ oraz list F. Synakiewicza pt. Oktawa Ś. Franciszka czyli Odpis na świętokradzka satyrę przeciwko temu świętemu rzucona w roku 1784 dnia 4 września pod tytutem: W dzień Ś. Franciszka ..., Wwa 1785.

Osobną grupę stanowiły katechizmy, np. J. S. Wujkowskiego Chleb duchowny, Kr. 1781 czy Nauk katechizmowych poczatki, Kr. 1785.

Z przekładów należałoby wymienić: tłumaczone z języka francuskiego: przez A. M. Prokopowicza Zebranie krótkie chronologiczne historii kościelnej C. Fleury'ego, t. 1-2, Kr. 1786 oraz J. B. Massillona Kazania dla panów ..., w przekładzie J. Jabłonowskiego, Kr. 1788; z łaciny: Listy papieża Klemensa XIV Ganganellego. Uwagi, mowy, kazania, panegiryk, Kr. 1779, a także niemieckie thumaczenie Rautenstraucha Propozycji J Światobliwości Papieskiej Piusowi VI przedtożone od JKMci pana de Laurier roku 1782 w Wiedniu. Z odpowiedziami z strony Piusa VI, Wwa 1785.

\section{LITERATURA POPULARNO-NAUKOWA}

„Jednym z charakterystycznych zjawisk w rozwoju nauki polskiego oświecenia była szeroka popularyzacja wiedzy, które to zadanie miały spełnić między innymi wydawnictwa popularno-naukowe przeznaczone dla szerokiego kręgu odbiorców, przede wszystkim zaś poradniki i kalendarze" ${ }^{28}$.

$\mathrm{Z}$ tego typu wydawnictw Dufour polecał dwa poradniki medyczne, popularyzujące wiedzę z zakresu położnictwa: J. Różańskiego Sztukę babienia. Dzieło bardzo potrzebne nie tylko odbierajacym po wsiach dzieci przy pologu, lecz też $i$ wszystkim, którzy oddaleni będąc, nie maja sposobności poradzenia się i wzywania na ratunek $w$ tej sztuce bieglych ... z rozmaitych autorów francuskich i niemieckich zebrana, Wwa 1786 i O staranności koło kobiet od czasu rozwiazania onych aż do końca połogu, tudzież o różnych chorobach, którym przez ten czasu przeciag podlegaja, Wwa 1792 oraz jeden poradnik ogrodniczy F. Siarczyńskiego Sztuka ogrodnicza czyli O ogrodnictwie, zawierajaca przepisy chodzenia przyzwoitego około ogrodów kwiatowych, kuchennych i sadów, Kr. 1782.

W Katalogu znalazł się także Kalendarz ciagty wyrachowany od 1790 aż do 1900 roku, Wwa, brak roku, który jak inne tego typu ówczesne wydawnictwa dostarczał informacji na temat najnowszych zdobyczy nauki i techniki.

Ostatnie miejsce zajęly w Katalogu dwa czasopisma. Pierwsze z nich to „Monitor" - polski periodyk moralny epoki stanisławowskiej, który wychodził dwa razy w tygodniu w latach 1765-1785. Drukował go najpierw W. Mitzler de Kolof, a ostatnie dwa roczniki (tj. od 1784) - P. Dufour, redagowali zaś kolejno: I. Krasicki, F. Bohomolec, J. E. Minasowicz i J. J. Boelcke ${ }^{29}$. Drugie - to redagowana przez J. Mejera „Biblioteka Fizyko-Ekonomiczna Nauczająca i Bawiąca”, przekład fran-

28 D. Hombek, Reklama wydawnicza ..., s. 117.

${ }^{29}$ Drukarze dawnej Polski od XV do XVIII wieku, t. 3 cz. 2, Mazowsze z Podlasiem, Warszawa 2001, s. 45-46. 
cuskiej „Bibliothéque Phisico-Economique Instructive et Amusante” założonej w 1788 roku i zawierającej uwagi doświadczone w gospodarstwie wiejskim, a także informacje o nowych wynalazkach.

Czasopisma te, podobnie jak 64,5\% tytułów zamieszczonych w tym Katalogu, pochodziły z własnego repertuaru wydawniczego Dufoura, a 36,5\% - to pozycje wzięte w komis od innych drukarzy.

Na ogólną liczbę 164 utworów dramatycznych, 130 - stanowiły remanenty Dufoura, 21 zaś to produkcja oficyn obcych m.in. 11 - tytułów to druki M. Grölla, 7 - I. Grebla oraz po 1 - drukarni A. Dziedzickiej i księgarni J. A. Posera.

Utwory prozaiczne składały się z: 95 remanentów Dufoura i 38 pozycji wziętych w komis (w tym 23 - od I. Grebla, 10 - M. Grölla, po 2 z Drukarni Wolnej i P. Zawadzkiego i 1 - od A. Dziedzickiej). Nowości wydawnicze reprezentowane były przez następujące powieści: Niestałość w mitości czyli Awantury Markiza de Vandreville J. B. Argensa, Wwa 1793, Pamiętniki pana de Ravanne J. de Varenne'a, t. 1-4, Wwa 1792-1793 i Teatr dla społeczności S. F. Genlis, Wwa 1793.

W poezji dominowały pozycje komisowe: M. Grölla - 6, I. Grebla - 4, Drukarni Akademii Wileńskiej - 2 i ks. trynitarzy - 1. Własne remanenty Dufoura to 11 tytułów.

Spośród książek naukowych 22 - to remanenty, a 19 - wzięte w komis: 16 - od I. Grebla, 2 - M. Grölla i po 1 - z Drukarni Akademii Wileńskiej, A. Dziedzickiej i pijarów. Jedyną nowością była W. R. Karczewskiego O prawach fizycznych i moralnych świata, t. 1-5, Wwa 1791-1793.

Na 25 utworów publicystycznych 10 - to remanenty, a 2 - komis od I. Grebla.

Literatura religijna była zdominowana przez 9 utworów wziętych w komis od I. Grebla, a tylko 4 stanowiły - remanenty własne Dufoura.

Książki popularno-naukowe to 1 remanent, 1 - komis od I. Grebla i jedna nowość pt. Wykład snów nocnych, b.m. 1793.

Obydwa adnotowane w Katalogu czasopisma były remanentami księgarskimi.

Ogólna liczba remanentów, pochodzących z drukarni Dufoura wynosiła więc 275 tytułów, natomiast 103 - to pozycje wzięte w komis. Wśród nich zdecydowanie najwięcej, bo 61 stanowiły publikacje oficyny I. Grebla, następne natomiast to: 29 M. Grölla, po 3 - z Drukarni Akademii Wileńskiej i A. Dziedzickiej, po 2 - z Drukarni Wolnej i P. Zawadzkiego oraz po 1 - z drukarni pijarów, ks. trynitarzy, J. A. Posera i Mitzlera de Kolof. Zaledwie 5 utworów w całym Katalogu to nowości. W pozostałych 30 przypadkach nie podano nazwiska drukarza, miejsca i roku wydania.

Analiza powyższych danych wyraźnie wskazała, że Katalog Dufoura z 1793 roku jest katalogiem retrospektywnym.

Spośród autorów polskich najczęściej wymieniany był W. I. Marewicz, po nim I. Krasicki i kolejno: A. K. Czartoryski, J. Potocki, J. K. Kossakowski, A. Naruszewicz, D. M. Krajewski i F. S. Jezierski.

Wśród thumaczy pierwsze miejsce zajęli równorzędnie: W. Bogusławski i J. Baudoin, za nimi zaś: F. Zabłocki, A. M. Prokopowicz, J. I. Przybylski, K. Wichliński i T. K. Węgierski. 
Autorem obcym zdecydowanie przodującym, był Molier, po nim Voltaire, a następnie: L. S. Mercier, J. F. Marmontel, Ch. Montesquieu, C. Goldoni i J. P. Florian.

Repertuar wydawniczy Dufoura, odzwierciedlony w jego Katalogu, świadczy o dynamicznych przemianach w świadomości społecznej i nasilaniu się poczucia więzi narodowościowych. Dzieła tłoczone były zgodnie z tendencjami europejskimi, a nawet szerzej - światowymi. Pomimo iż Dufour nastawił się głównie na wydawanie literatury pięknej, nie zrezygnował jednak z popularyzowania książki naukowej, a także pozostałych typów omówionej literatury, która cieszyła się zainteresowaniem, zwłaszcza wśród czytelników warstw średnich. Pamiętać bowiem należy, iż książka była w owym czasie „towarem” drogim, ale skoro ją wydawano to znaczy, że popyt na nią ciągle rósł.

Analiza językowa zaś dostarczyła materiałów świadczących o zwycięskiej walce polszczyzny nad językiem łacińskim, jaka dokonała się właśnie w czasach stanisławowskich.

Katalogi księgarskie stanowią podstawowe źródło informacji o drukach znajdujących się w obiegu handlowym. Są to spisy książek zarówno polskich, jak i obcych, czasopism, a także nut, rycin, map oraz różnych innych towarów np. drogeryjnych, przeznaczonych do sprzedaży w księgarniach.

Stale postępujący - szczególnie dynamiczny w XVIII wieku - rozwój handlu księgarskiego i form reklamy książki wpłynął na zróżnicowanie się poszczególnych typów katalogów księgarskich. Były to katalogi: wydawnicze, nakładowe, nakładowo-sortymentowe i aukcyjne.

Katalog księgarski z samego założenia powinien wykazywać pozycje znajdujące się w sprzedaży, tymczasem w omawianym - w niniejszym artykule - Katalogu Dufoura pojawiła się dość obszerna zapowiedź drugiego tomu Prawa politycznego i cywilnego Korony Polskiej $i$ W. Ks. Lit. A. Trębickiego, ze szczegółami dotyczącymi warunków prenumeraty całego dzieła.

Jednak Katalog ten jest zdecydowanie katalogiem sortymentowym, rejestrującym w 95\% remanenty księgarskie z lat 1774-1792.

Zawartość tego najbardziej reprezentatywnego dla Dufoura katalogu, zestawiona z innymi formami reklamy książki w XVIII wieku pozwoli stworzyć pełny obraz działalności wydawniczo-księgarsko-nakładowej Piotra Dufoura.

Opracowanie i szersze udostępnianie treści katalogów księgarskich ma duże znaczenie informacyjne, edukacyjne i naukowe, tym bardziej, że są one na ogół nieznane i rozproszone po wielu bibliotekach naukowych w kraju. 
Tabela 1. Typy piśmiennictwa reprezentowane w katalogu

\begin{tabular}{|c|c|c|c|c|c|c|c|c|c|c|c|}
\hline \multicolumn{4}{|c|}{ Literatura piękna } & \multicolumn{2}{|c|}{ Książki naukowe } & \multirow{2}{*}{ 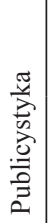 } & \multirow[b]{2}{*}{ 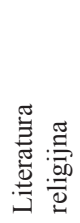 } & \multicolumn{2}{|c|}{$\begin{array}{l}\text { Książki popularno- } \\
\text {-naukowe }\end{array}$} & \multirow{2}{*}{$\begin{array}{c}\text { Czaso- } \\
\text { pisma }\end{array}$} & \multirow{2}{*}{ Varia } \\
\hline $\begin{array}{l}\text { dzieła } \\
\text { zebrane }\end{array}$ & dramat & poezja & proza & $\begin{array}{c}\text { mat. } \\
\text { przyrodn. } \\
\text { i techniczne }\end{array}$ & $\begin{array}{l}\text { humani- } \\
\text { styczne } \\
\text { i społeczne }\end{array}$ & & & $\begin{array}{l}\text { kalen- } \\
\text { darze }\end{array}$ & $\begin{array}{l}\text { porad- } \\
\text { niki }\end{array}$ & & \\
\hline 1 & 164 & 32 & 139 & 18 & 27 & 25 & 14 & 1 & 3 & 3 & 6 \\
\hline \multicolumn{4}{|c|}{336} & \multicolumn{2}{|c|}{45} & & & \multicolumn{2}{|c|}{4} & & \\
\hline
\end{tabular}

Tabela 2. Struktura językowa zawartości katalogu

\begin{tabular}{|c|c|c|c|c|c|c|c|c|c|c|c|c|c|}
\hline \multirow{2}{*}{\multicolumn{2}{|c|}{ Język }} & \multicolumn{4}{|c|}{$\begin{array}{l}\text { Literatura } \\
\text { piękna }\end{array}$} & \multicolumn{2}{|c|}{$\begin{array}{c}\text { Książki } \\
\text { naukowe }\end{array}$} & \multirow[b]{2}{*}{ 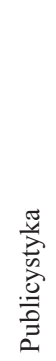 } & \multirow[b]{2}{*}{ 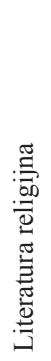 } & \multicolumn{2}{|c|}{$\begin{array}{c}\text { Książki } \\
\text { popularno- } \\
\text {-naukowe }\end{array}$} & \multirow[b]{2}{*}{ 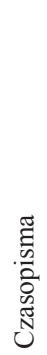 } & \multirow[b]{2}{*}{ 嗬 } \\
\hline & & 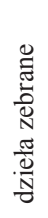 & 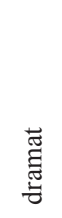 &  & $\begin{array}{l}\widetilde{N} \\
\stackrel{\tilde{L}}{2}\end{array}$ & 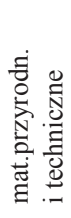 & 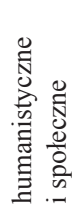 & & & 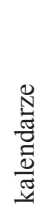 & 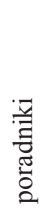 & & \\
\hline \multicolumn{2}{|c|}{$\begin{array}{l}\text { Literatura oryginalna } \\
\text { w języku polskim }\end{array}$} & 1 & 35 & 18 & 40 & 6 & 15 & 20 & 10 & 1 & 3 & 2 & 3 \\
\hline \multirow{7}{*}{$\begin{array}{c}\text { Przekłady } \\
\text { na język } \\
\text { polski }\end{array}$} & $\begin{array}{l}\mathrm{z} \text { jęz. } \\
\text { franc. }\end{array}$ & & 93 & 9 & 83 & 9 & 7 & 3 & 2 & & & 1 & 1 \\
\hline & $\begin{array}{l}\mathrm{z} \text { jęz. } \\
\text { niem. }\end{array}$ & & 10 & 3 & 6 & 2 & 4 & 2 & 1 & & & & 2 \\
\hline & $\begin{array}{l}\text { z jęz. } \\
\text { łacińs. }\end{array}$ & & & 2 & 3 & & & & 1 & & & & \\
\hline & $\begin{array}{l}\text { z jęz. } \\
\text { greck. }\end{array}$ & & & & 2 & & & & & & & & \\
\hline & $\begin{array}{l}\text { z jęz. } \\
\text { włosk. }\end{array}$ & & 22 & & 2 & & 1 & & & & & & \\
\hline & $\begin{array}{l}\text { z jęz. } \\
\text { rosyj. }\end{array}$ & & 2 & & & & & & & & & & \\
\hline & $\begin{array}{l}\text { z jęz. } \\
\text { angiel. }\end{array}$ & & 2 & & 3 & 1 & & & & & & & \\
\hline & & 1 & 164 & 32 & 139 & 18 & 27 & 25 & 14 & 1 & 3 & 3 & 6 \\
\hline
\end{tabular}


AGNIESZKA ZYCH-KWIATKOWSKA

\title{
BOOK ASSORTMENT OF PIOTR DUFOUR IN VIEW \\ OF THE CATALOGUE FROM 1793
}

\begin{abstract}
Summary
The article presents the most significant book catalogue of a Warsaw printer, bookseller and publisher of the Polish Enlightenment, Piotr Dufour. It also analyses the text structure of the catalogue from the point of view of the content and form of the works that it includes.

The catalogue includes 336 Polish and foreign literary texts including: 164 plays, 139 prose works and 32 poetic works. These texts are dominated by 176 translations from French followed by Polish literature - 92 titles, and translations in: Italian - 24 titles, German - 16 titles, English - 5 titles, Latin -3 titles and two from Greek and Russian.

It is an assortment catalogue, mostly (95\%) presenting book inventories from 1774-1792.

The works discussed in the article, representing Belles-lettres, scientific literature, journalism, religious and popular science literature create a full picture of Piotr Dufour's activity as a publisher, bookseller and editor.
\end{abstract}

